\title{
Dominique Manotti and the Roman Noir
}

\author{
Angela Kimyongür
}

\begin{abstract}
Dominique Manotti's crime fiction novels have as their setting a variety of contemporary political and economic issues, a deliberate choice for an author who sees her work not as traditional detective novels, where order is reestablished upon the resolution of an individual crime, but rather as romans noirs, where crime is the product of a dysfunctional society. As a female crime writer, Manotti has rejected the notion of a distinct genre of "polar féminin" together with the ghettoization implicit in such a notion. The aim of this paper is to consider Manotti's contribution to female-authored crime fiction in France, in the light of her opposition to the notion of a "polar féminin." Her choice of a gender-neutral pseudonym, the featuring of a male detective in her earlier novels, and the adoption of sociopolitical themes in her work would seem to suggest that gender is not a primary concern. However, closer consideration of a selection of novels suggests that Manotti does reflect on questions of gender, although not always from a feminist or even a uniquely female perspective. Particular attention will be paid to the representation of marginalized gender, sexual, and ethnic identities in her novels, and to the way in which she goes beyond simplistic sexual binarisms that define women as victims and men as their oppressors to offer a more nuanced contribution to female-authored crime fiction than is suggested by the term "polar féminin."
\end{abstract}




\section{Introduction}

Dominique Manotti is an academic historian by training, a specialist in nineteenth-century economic history at the University of Paris. She has also been a political activist, involved in militant groups and trade unions during the 1960s and 1970s. She came to crime writing relatively late in life, publishing her first novel Sombre Sentier in 1995 at the age of fifty three. This first novel, which garnered a number of literary prizes in France, was followed in 1997 by A nos chevaux, Kop in 1998, Nos fantastiques années fric in 2001, Le corps noir in 2005, Lorraine Connection in 2006, and Bien connu des services de police in 2010. Her most recent novel, L'Honorable société, published in March 2011, is a collaborative production with French crime writer DOA1 and was awarded the major French crime writing prize, the Grand Prix de Littérature Policière, in November 2011. The critical and popular success of her work has ensured that a number of these novels have been translated into English.2 In 2008 Lorraine Connection won the Crime Writers' Association International Dagger for the best crime novel translated into English, an award for which Dead Horsemeat was shortlisted in 2006.

Manotti's interest in using the crime novel for the purposes of sociopolitical critique can be seen in the way in which her novels regularly present the tensions in a society polarized between those endowed with power and authority, such as politicians, the police, those with vested interests in the world of business, and those living in one way or another on the margins of society, whether they be members of ethnic minorities, illegal migrant workers, or sex workers. Closer examination reveals that she also uses her novels to reflect on questions of gender, not always approaching them from a feminist nor even a uniquely female perspective, but rather through this same optic of marginalized identities, a preoccupation that reflects her definition of the roman noir as a form that offers "un regard sur le côté sombre, opaque, criminel, tragique de la société...sur les marges considérées comme révélatrices de la société tout entière." / "a look at the dark, opaque, criminal, tragic side of society...at the margins that reveal much about society as a whole" ("Chéries noires" 92).

The following analysis will explore Manotti's preoccupation with these margins, focusing on her representation not only of marginalized, socially excluded groups, but also of marginalized sexual and gendered identities. It will focus on the way in which these groups are subjected to differential treatment: violence, particularly sexual violence, discrimination, and the abuse of power relations. The analysis will demonstrate not only that Manotti goes beyond simplistic sexual binarisms that define women as victims and men as their oppressors, but that her approach to marginalization can be viewed in the light of the concept of intersectionality, whereby gender difference intersects with other categories of difference, such as ethnicity, sexuality, class, or nationality, in such a way as to reinforce difference, thereby creating an additional weight of inequality or injustice (Lykke 50). In addition to these thematic considerations, Manotti's adoption of some of the ostensibly masculine narrative strategies of the roman noir, such as tough, independent investigators, violent plots, and an emphasis on the dark underbelly of society, will enable a view to be formed of her contribution to the female-authored roman noir in France, particularly in the light of the way in which she has rejected categorization as a writer of "polars féminins." Discussion will focus upon three of her novels: Sombre Sentier, the first of a trilogy featuring male superintendent Théodore Daquin; Nos fantastiques années fric, which introduces female investigator Noria Ghozali; and Bien connu des services de police, which features a fuller development of Ghozali's character. These texts are chosen as being particularly pertinent to the discussion of sexual, gender, and ethnic identities. 


\section{Manotti, Crime Writing and the French Context}

Manotti has attributed her decision to write crime fiction to a sense of political disillusionment and her recognition of the limits of political activism, both of these factors linked, in her eyes, to the socialists' accession to power in 1981. According to her website biography, 'L'arrivée de Mitterrand au pouvoir sonne, d'une certaine façon, comme le glas des espoirs de transformation radicale de la société. Alors, le roman noir apparaît comme la forme la plus appropriée pour raconter ce que fut l'expérience de ma génération." / "In a way, Mitterrand's accession to power sounded the death knell for any hopes of radical social change. The crime novel seemed then the most appropriate form in which to recount my generation's experience" ("Biographie"). She identifies the kind of crime fiction she writes as roman noir, in contradistinction to the roman policier. Her definition of the roman policier is reminiscent of the "whodunit," as defined in Tzvetan Todorov's typology of detective fiction, according to which a crime is committed at the beginning of the novel, is subsequently investigated, and a resolution to the mystery (usually the identification of the criminal) is proposed at the end of the novel. The story of the crime and the story of the investigation remain separate (Todorov 44). For Manotti, the final resolution typical of the roman policier means that the genre is associated with the reestablishment of order:

Un (ou plusieurs) crime, donc un désordre, intervient au début du roman. Un (ou plusieurs) enquêteur...mène une enquête, qui aboutit à la découverte du ou des coupables et au rétablissement de l'ordre. Le roman policier est par définition un roman d'ordre. Le mal existe, mais en fin de compte, l'ordre est restauré.

One or more crimes, in other words a disruption of order, occur at the start of the novel. One or more investigators...lead an investigation that culminates in the discovery of the guilty party, or parties, and in the restoration of order. The detective novel is, by definition, a novel about order. Evil exists, but in the end order is restored. ("Splendeurs et mystères")

The roman policier is also, normally, the story of an individual criminal act. Manotti's roman noir is different in two key respects: first, where the roman policier is characterized by the reestablishment of order, the roman noir is based on continuing disorder; if order is in some way reestablished at the novel's end, the respite is only a temporary one; second, where the roman policier focuses on individual crimes, the roman noir directs its gaze toward crime in society:

Le roman 'noir', lui, enracine les crimes dans les circonstances sociales dans lesquelles ils sont commis. Ce n'est plus l'individu seul qui est criminel, c'est le monde de souffrance, de misère, de violence et de corruption dans lequel nous vivons qui produit les individus criminels....Le rétablissement de l'ordre, s'il a lieu, n'est jamais que le rétablissement précaire, identifié comme tel, d'une apparence d'ordre et de paix.

The "noir" novel roots crime in the social circumstances within which it is committed. The criminal is no longer a lone individual. It is the world of suffering, poverty, violence, and corruption in which we live that produces criminals....The restoration of order, if it occurs, is never more than a precarious restoration, identified as such, of a facade of order and peace. ("Splendeurs et mystères")

Manotti herself associates the roman noir with the American hardboiled novel of the 1930s and 1940s because of their common immersion in the darker sociopolitical realities, 
"enraciné dans les luttes sociales, dans la politique, dans le ruisseau, dit Chandler, en tout cas dans un type de réalisme du désespoir et de la fatalité" / "rooted in social struggles, in politics, in the gutter, as Chandler says, at any rate in a realism of despair and fatalism" ("Chéries noires" 93), and she identifies James Ellroy as a particular influence on her work (Belhadjin, "Interview" 178). As Alistair Rolls and Deborah Walker have pointed out, the term noir has been used so much that it is inherently unstable as a critical term (6). While this instability is indeed frequently in evidence in critical discourse, Manotti's focus on the sociopolitical and on characters and plots that challenge the established order is, as has been noted by Lee Horsley, typical of the noir genre (12). Consequently, I have chosen to retain Manotti's use of the term roman noir in discussing her crime fiction.

In the French context, Manotti's focus on crime as symptomatic of a disordered society, together with her association with left-wing politics, suggests parallels between her novels and those of the writers of the néo-polar, who share a similar radical, left-wing background to her own.3 The néo-polar was a politically engaged form of crime fiction that emerged in the wake of the events of May 1968 and reflected the social and political turmoil of that time. In a general overview of the development of the roman noir in France, Claire Gorrara characterizes the subgenre of the néo-polar as one in which "the forces of law and order are depicted as little more than the flip side of organised crime. Politicians and statesmen are corrupt and repressive, whilst authority figures at all levels prove equally flawed and exploitative" (16). The themes underpinning the narratives in all of Manotti's novels are attuned to this politically inspired tradition of social critique. Corruption is a mainstay of her narratives: the corruption of political life, and corruption within the police force and in industry are underpinned by a persistent focus on excluded or marginalized groups in society, such as ethnic minorities, illegal migrant workers, the unemployed, and sexual minorities. These themes are explored against a backdrop of the seamy side of public life in which drug use, drug trafficking, and prostitution are pervasive. While the néo-polar is, by the mid 1980s, generally accepted to have "run its course" (Gorrara 17), its critical take on the French political establishment can still be found in the less radical, and less nihilistic, roman noir engagé, a politically committed form of crime fiction associated with writers such as Didier Daeninckx and Thierry Jonquet. Born in 1942, and a young, politically active woman in 1968, Manotti is of the same generation as several of these writers. 4 Her writing, motivated by her declared disillusion with the political establishment, has a similar outlook in its critique of political and social life in contemporary France.

\section{The Polar Féminin}

While it is a fairly straightforward matter to situate Manotti's work politically, the question of the relationship between her gender and her crime writing is more complex. Women writers of crime fiction have not traditionally dominated the genre in France in the way in which the British "Queens of Crime" such as Agatha Christie, Dorothy L. Sayers, Margery Allingham and, more recently, P. D. James, among many others, have shaped British crime writing in the course of the twentieth century. Indeed, the genre in France is usually perceived to be a masculine one. Publishing house Gallimard's crime series, the Série noire, published scarcely any novels by women until the 1990s.5 Deborah Hamilton's research for her 1994 doctoral thesis on French women crime writers, however, revealed a rather different picture, uncovering more than 140 women crime writers of some 750 texts published between the 1920s and the 1990s. Yet it also revealed the marginalization of the works of female crime writers in relation to a genre assumed to be a masculine one, an assumption aided by the fact 
that women's identities were frequently camouflaged by male pseudonyms, some deliberately chosen, others imposed by publishers. 6

It was not until the 1980s that women crime writers began to emerge from this anonymity to come to the attention of the public and critics in a more sustained way, a development seized upon by the media as constituting the arrival of a new subgenre of crime writing: the polar féminin.7 As Véronique Desnain has pointed out, this label creates an immediate ambiguity in that it could designate crime fiction written by or for women, or focusing on women ("Gender and Genre" 89). Nor was the label associated with an overwhelmingly positive acknowledgment of the contribution of women writers to crime fiction as can be seen in the example of the annual Saint-Nazaire crime writing festival, which, in 1992, was dedicated to women writers. To coincide with the festival, Gallimard produced an anthology of short stories entitled Noir de femme. The text on the back cover of the anthology proclaimed, without a hint of irony: "Noir de femme, c'est 16 histoires de femme racontées par 16 hommes" / "Noir de femme contains 16 stories about women told by 16 men" (qtd. in Hamilton 1), thus effectively silencing women's voices in a publication designed to celebrate their place in the genre, while the festival posters promoted the event with an image of a black-clad femme fatale. Neither the anthology nor the festival promotion did anything to dispel stereotypical assumptions about crime fiction as a masculine genre in which women apparently have no agency as writers, while female characters are either femmes fatales or victims. 8

Manotti has expressed her own reservations about the concept of a polar féminin in an article with the ironical title "Chéries noires," a phrase alluding to one of the more disparaging labels attached to female-authored crime fiction. She is critical of the polar féminin on a number of counts: first, it incorrectly implies that women have not written crime fiction before, and have no history of doing so; second, it constitutes a form of ghettoization, randomly lumping all female crime writers together; and finally, it is "une façon de nous renvoyer à l'éternel féminin" / "a way of sending us back to the stereotype of the eternal feminine" (95). In other words, it is predicated on the assumption that there is something discernibly and inescapably feminine about women's crime writing, that it is characterized by "Complicité, tendresse, solidarité, amour, amitié" / "Complicity, tenderness, solidarity, love, and friendship" (95). Critical of such an essentialist view of women's crime writing, and given her reservations about the polar féminin, Manotti appears to have sought to distance herself in her own writing practice from an obviously gendered form of crime writing preferring to retain "un droit à l'universel" / "the right to speak for all" (91). Her choice of a gender-ambiguous forename, the fact that in her first three novels at least, the main investigating figure is male, and that the publicity blurb on at least three of her novels identifies her style as "brutal,"9 a value that might be considered to have masculine associations, would seem to indicate at the very least that Manotti is keen to dissociate herself from stereotypical assumptions about women's crime writing. Her choice of an androgynous pseudonym and of a male detective are features she shares with another high-profile female French crime writer Fred Vargas whose Commissaire Jean-Baptiste Adamsberg is the recurrent male detective, together with his side-kick inspector Danglard, in a series of highly successful novels. Vargas has identified her choice of male detective as a strategy intended to avoid the weight of stereotyping that can burden female characters and their creators: "Contrairement aux hommes, les femmes sont cernées par les clichés littéraires, la vamp, la pute, la mère, la maîtresse, la niaise" / "Unlike men, women are defined by literary clichés: the vamp, the whore, the mother, the mistress, the ingénue" (Santucci, qtd. in Barfoot 38); whereas male characters, are perceived as a blank canvas. Vargas has challenged gender 
stereotypes by characterizing Adamsberg as a reflective, philosophical detective; Danglard is a single father to five children, while Camille, Adamsberg's lover, is a musician and plumber.

Vargas's strategy, in common with that of other French women crime writers, of avoiding female protagonists has been explained as a rejection of the unrealistic American model of the "superwoman" detective who "can sprint through a hail of bullets without breaking sweat whilst thinking up clever ways to entrap the villain" (Desnain "La femelle de l'espèce" 184). Nonetheless, there are increasing numbers of women writers, such as Maud Tabachnik, Andréa Japp, and Dominique Sylvain, who have adopted female investigative figures. Tabachnik has commented on the frequency of female stereotypes in the roman noir and views the adoption of active female characters as an encouraging development that offers positive role models to young women and challenges stereotypical perceptions: "Tant que les rôles dévolus aux personnages féminins n'étaient que ceux de garces ou de victimes, il était difficile pour les filles de s'identifier à des rôles positives, et pour les garçons d'imaginer que les femmes pouvaient être autre chose que des hystériques perpétuellement effrayés ou des êtres dangereux" / "As long as the roles allotted to female characters were only those of slut or victim, it was difficult for young women to identify with positive roles and for young men to imagine that women could be anything other than constantly frightened hysterics or dangerous individuals" (129). Her own fictional practice, which has featured lesbian journalist Sandra Khan in a number of novels, challenges these stereotypes. She does so not so much through her choice of a lesbian heroine since, as Nicole Décuré has pointed out, in Tabachnik's novels "lesbianism is portrayed simply as a fact of life" (57), but rather by foregrounding women who refuse victimhood and who fight back. Un été pourri, published in 1994, is a case in point. It features a series of murders of men who have also been sexually mutilated, crimes that seem to point to a serial killer. It transpires that three of the four victims are responsible for a crime against a woman and that each one has been killed by a different woman, each one of whom is presented as having ample justification for the crimes committed. Indeed, unusually in crime fiction, the reader is encouraged to sympathize with the lawbreakers, one of whom is Sandra Khan herself.

Manotti's persistent focus in her novels on corruption in political and economic life would seem to indicate a decision to set aside questions of gender, as Vargas has done, in order to speak with a nongendered voice that engages in a broad critique of contemporary French society, going counter to what Barfoot has identified as "male critics' insistence that women writers do not have political intentions and that criticism of society remains a male preserve" (54). However, while Manotti does indeed demonstrate that women crime writers can and do have political intentions, questions of gender have not been set aside but remain embedded in her novels.

\section{Investigators on the Margins}

Although a feminist in her personal life, Manotti does not pursue an overtly feminist agenda in her novels, nor did she feel obliged to feature a female investigator, at least not in her first three novels. It may be that, like Vargas, she was anxious to avoid the burden of female stereotypes, though she has also admitted that she feels less comfortable with female characters: "J'ai beaucoup de mal avec les personnages féminins. Cela provient sans doute de mon propre univers: j'ai toujours été féministe...mais...j'ai toujours milité dans un univers très masculin" / "I have a lot of difficulty with female characters. This is doubtless the result of the world I live in: I've always been a feminist...but have always militated in a very masculine world" ("Du militantisme" 47). The choice of Théo Daquin as a central character 
in her first three novels seems at first sight to conform to expectations of the traditional hardboiled detective. He works in the drugs squad, a tough and very masculine environment. Like his colleagues, he can be ruthless. In Sombre Sentier, he shows that he is not above hitting or threatening a suspect during an interrogation, and he plays on the vulnerability of his informer, Soleiman, by threatening him with deportation to Turkey if he fails to provide the information Daquin needs.

Daquin, however, is not the stereotypical hardboiled detective that first appearances might suggest. Manotti accords considerable attention to his private life, something not infrequently seen as a preoccupation of women writers. While he lives alone, unlike the often solitary, dysfunctional, wisecracking detective of the hardboiled genre, Daquin is a sociable man, a natural leader of his team, a physically imposing figure from a privileged background who has achieved early success in his career, yet also a cultivated man - his home is named the "Villa des Artistes" - who appreciates culture in others. In terms of R. W. Connell's theorization of masculinities, this would appear to associate Daquin firmly with the notion of "hegemonic masculinities" (77-81), a category encompassing "cultural and social practices that legitimize gendered power differentials, privileging some men and making it possible for them to successfully dominate and subordinate women and other men" (Lykke 63). Although Daquin does at times dominate and subordinate others, both men and women, by virtue of his professional status and the force of his character, he is more complex than this would suggest. Many of his characteristics could be considered to be stereotypically feminine. His relationships with his lovers are frequently characterized by tenderness and sensuality; he generates a supportive camaraderie with his team and demonstrates a deep attachment to longstanding friends - for example, Lenglet, who, by the second novel, is dying of AIDS and whom he visits in hospital - or to trusted colleagues. His sensuality extends to an appreciation of good food and drink, both of which he likes to prepare for others.

However, the characteristic that most obviously distinguishes him from the hardboiled model to place him on the margins is his sexuality. Daquin is often described as being gay, though his sporadic relations with, and sensual appreciation of women indicate his orientation to be bisexual rather than homosexual. The "aussi" in his comment "J'aime aussi les garçons" / "I like boys too" makes this clear (270). His orientation places him in Connell's category of "subordinate masculinities," in which he includes gay men (78), a categorization which, in Daquin's case, intersects with his hegemonic masculinity to create some interesting tensions. The dynamics of the unequal relationship between him and his informer Soleiman are a case in point. An exiled Turkish left-wing militant, on the run from the police in his homeland, and without official papers in France, Soleiman has been recruited by Daquin, whose initial abuse of his power, both sexual and judicial, over the younger man in the early stages of their relationship places Soleiman in the category of " marginalized masculinities'...men who are subjected to the power of other men because of societal power structures based, for example, on ethnicity and/or class" (Lykke 64). While this power imbalance between the two is never fully rectified - for example, it is never made unambiguously clear whether Soleiman accepts Daquin's sexual demands because he himself is gay or simply because his ethnic and legal marginality does not allow him the luxury of choice - Daquin's dominance is gradually replaced by a genuine tenderness and affection for the younger man. As this relationship might suggest, Daquin is far from being a typical male detective, hardboiled or not, though while his sexuality is not mainstream, he is secure enough in his class and professional identity for it not to marginalize him in the workplace. His colleagues accept him unquestioningly, while his immediate senior officer betrays only an amused tolerance at his sexual preferences. 10 
Daquin's past, however, does set him apart. Recurrent motifs, particularly at moments of crisis, are the early traumas that have marked him and continue to haunt him: the death of his mother from drugs and alcohol when he was thirteen, the frigidity of his relationship with his father, and, crucially, his own experience of sexual violence: his rape by an unknown man in the year of his mother's death. These traumatic experiences, and particularly the latter, enhance his empathy with victims and fuel both the sense of moral outrage that he feels when confronted with injustice and his determination to get to the truth. This is most obviously the case in his empathy for victims of rape. In Sombre Sentier he is involved in the interviewing of Dorothée Marty, a prostitute raped by a client. Only Daquin is sufficiently attuned to notice her physical reaction when questioned about this man. Shocked that none of the other officers present noticed anything, he concludes that they are either not good at their job or else they simply do not care.11 She is taken aback at the way in which his instinctive understanding of her past trauma counters her expectations of police behavior. This empathy extends to other vulnerable victims, shown for example in his outrage at the discovery of pornographic images of children held in the cellar of a couple involved in the sexual trafficking of Thai children, and his explosion of anger when their secretary proffers the excuse that the children's parents should have taken better care of them (89). Such emotional involvement with and understanding of victims provides a sharp contrast with the wisecracking and sardonic detectives of the hardboiled tradition to whom Daquin, after all, bears only a superficial resemblance. This contrast is particularly highlighted through his difference from subordinate officers Romero, Thomas, and Santoni, whose aggressive heterosexuality and not infrequent abuse of women at their mercy is shown by Manotti to be typical of male behavior within the police force.

The choice of the bisexual Daquin as central investigating figure in Sombre Sentier enables an exploration of a complex masculine identity, very different from the traditional model of the hardboiled detective. It was not until Manotti's fourth novel, Nos fantastiques années fric, that she introduced a female investigator, Noria Ghozali, a woman from a Maghrebi background whose development is continued in Bien connu des services de police. Ghozali's introduction enables Manotti to explore a female gendered identity at odds with the predominantly masculine environment of the police force. Ghozali's back story has a significant bearing on her character, having left home and family just before her $18^{\text {th }}$ birthday, a departure represented in the opening section of Nos fantastiques années fric as an emphatic rejection of paternal and patriarchal authority. Having abandoned the security of home and family, she seeks it through her work as a police officer, which offers her an affirmation of identity and status: "Un travail, stable. Plus que ça, une carte, une place dans la vie, un rôle à jouer, du côté de la loi, du côté de la force" / "A stable job. More than that, it gives me an identity, a place in life, a role to play, on the side of the law, on the side of strength" (17). While her independence and professional assurance would seem to indicate that her gender is not problematic for her, she is perennially conscious of others' perceptions of her as both gendered and ethnic other and, consequently, as inferior: "La plus jeune, la seule femme, la seule flic d'origine maghrébine, simple enquêtrice, statut subalterne et précaire" / "The youngest, the only woman, the only North African cop, a mere investigator with a subordinate and precarious status" (18). This comment demonstrates that Manotti sees her gender, ethnic, and, arguably, class identities as intersecting in a way that makes her multiply marginalized in the work place. Her heightened sensitivity to her sense of marginalization makes her aggressively defensive and instinctively suspicious of male colleagues: "Sur ses gardes: à l'instinct, un homme, son supérieur, méfiance" / "On her guard, instinctively suspicious of a man, her superior" (67). Despite these inner insecurities, she is perceived by those around her as strong; the word "une force" is applied to her several 
times, and her strength is equalled by her ambition. Conscious of her otherness, of a sense of being in some way on the wrong side of the tracks, she grasps every opportunity for promotion, unlike her male police partner, the more socially and professionally assured Bonfils. However, she is not solely motivated by ambition. Just like Daquin, she is driven by a desire for justice, a desire more apparent in Bien connu des services de police, which is set 20 years after her first appearance and sees a mature and more assured Ghozali, having risen through the ranks and now on course to become a superintendent (49). Manotti also evokes her private life, as she did with Daquin. The erotic attraction to Bonfils described in Nos fantastiques années fric has evolved into a sporadic sexual relationship, which has lasted over twenty years. However, her sexual identity continues to exhibit signs of her innate defensiveness. While her relationships with Bonfils and another colleague, Rodolphe, bring pleasure, they are also characterized by emotional detachment. Her relationship with the latter is no more than "épisodique et plaisante" / "occasional and agreeable" (51), while Bonfils ruefully observes that she never stays with him long: "Elle a toujours trouvé le moyen de fuir" / "She always manages to run away" (100). These characteristics make her, in a sense, the obverse of Daquin, the male detective whose sexual and emotional attachments are integral rather than peripheral to his life; while Ghozali's independence, emotional detachment, and lack of interest in domesticity and food are characteristics typically considered to be male traits. Manotti seems to be at pains to dispel simplistic gender stereotypes by deliberately blurring such distinctions.

Ghozali's introduction also enables Manotti to reflect on the marginalization of women in the police force. While Daquin's sexuality may appear to place him in a marginal category, in practice he is well integrated in the police hierarchy and with his immediate circle. As a white, male officer from a privileged background, his sexual difference has had a relatively minor impact on his professional life. As a woman who is neither white nor middle class, Ghozali's experience of intersecting marginalities has been very different. Her investigation into an arson attack takes her into police files that bring back traumatic memories of her early years as an officer in the security branch of the police, subjected to racist and sexist comments on a regular basis, her isolation exacerbated by the realization that she, not her tormentor, remained the outsider, in an institution that deemed his behavior acceptable: "le flic raciste, machiste et violent était bien mieux accepté par tous ses collègues,...qu'elle ne l'était elle-même, la femme, arabe, trop jeune, trop ambitieuse" / "the racist, macho, violent cop was much more accepted by all his colleagues than she was - the woman, the Arab, too young and too ambitious" (82).

Ghozali is not the only woman who suffers gendered discrimination within the police force. It is pervasive throughout the police hierarchy. Isabelle Lefèvre is a new recruit to the Panteuil station. On her first morning, she is subjected to a degrading sexualized assault by a male officer. The incident emphasizes her physical vulnerability particularly since the assault brings back a suppressed memory of another violent sexual assault that took place when she was a young girl: "ce souvenir enfoui si profond remonte du fond du ventre avec fracas" / "that memory, buried so far down, crashed back to the surface from deep within" (27). As in Daquin's case, her formative experience of sexual violence is a continuing trauma. However, her rapid resumption of self-control and her reassertion of authority in front of the male officers demonstrate her refusal to capitulate to such bullying: "OK, aujourd'hui, je la boucle....Mais si un mec, dans cette boutique, me touche de nouveau, je le tue" / "OK, I'll keep quiet about today.... But if any guy in this place touches me again, I'll kill him" (28). Such confidence stands in stark contrast to Ghozali's defensiveness and would seem to be 
linked to the fact that as a white officer Isabelle is marginalized only in gender terms unlike Ghozali, whose intersecting marginal identities make her more vulnerable.

A woman officer at the opposite end of the police hierarchy, superintendent Le Muir, is in a position of considerable power. However, Manotti does not take the ostensibly obvious option of presenting her as a positive female role model. Instead Le Muir stands as an example of the corrosive potential of power since her professional status has been gained by emulating the corrupt masculine behavior around her. The novel's plot revolves around her involvement in an arson attack on a building where illegal immigrants have been squatting. Her aim is "le nettoyage de la zone" / "the cleansing of the zone" (31) through a reduction of the high levels of criminality the area is known for, and the demolition of the dilapidated buildings the illegals inhabit, so as to allow commercial development of the area. Le Muir's attempts to do this legally have been frustrated, so she sets in motion a series of events that lead to a fire. Her lack of concern for the collateral damage this will inflict on the inhabitants of the burned buildings contrasts strongly with Ghozali's compassion for fellow members of ethnic minorities and with her passion for justice as she investigates the crime. However, the closing lines of the final chapter of Bien connu des services de police suggest that Ghozali remains marginalized within the police force. While she has attained some status as a female officer, she is outmaneuvered by the likes of Le Muir, who emulates the corrupt practices around her and succeeds: "[Le Muir] fait du travail de police un instrument de lutte idéologique, elle remplace la recherche de la preuve par une habile politique de communication et c'est elle qui gagne. Elle est dans l'air du temps, pas toi. Toi, tu es dépassée" / "Le Muir uses police work as a tool for her ideological battles, replacing the search for proof by a skilful communications policy, and she is the winner. She is in tune with the times, you aren't. You are out of your depth" (206).

Le Muir's political savoir-faire, rather than her gender, enables her to manipulate a male audience. Summoned to give an account of security issues in her area, she is confronted by a group of senior officers, all but one of them men. The only negative reaction to her emanates from the sole woman present, whose hostility remains unexplained, though it would seem to indicate that she alone sees through Le Muir's charm and finds it offensive: "Le Muir parcourt du regard son auditoire en évitant soigneusement la femme. Les hommes, tête levée, suivent chacun de ses gestes, chacune de ses intonations. Elle les tient, ils sont conquis" / "Le Muir ran her eyes across her audience, taking care to avoid the woman. The men, heads raised, followed her every gesture, her every intonation. She had them in her grasp, she had won them over" (65). Le Muir's position of power is associated with a masculine air of authority, evident from her first appearance: "La commissaire Le Muir sort de la préfecture de Bobigny, beau visage de blonde autoritaire, grande silhouette charpentée, en tailleurpantalon beige, une serviette en cuir fauve à la main" / "Superintendant Le Muir left the Bobigny police headquarters, her beautiful face, that of a domineering blonde, her figure tall and well built in a beige trouser suit, carrying a fawn leather briefcase" (29). In this description, the stereotypical markers of femininity, beauty and blondeness, are more than offset by the masculine elements of her presentation: height, build, trousers, and briefcase. Her performance is an essentially masculine one. Crucially, however, any failings are attributed to her femininity. Once hints of police involvement in the arson attack begin to emerge in the press, political advisors in the office of the minister of the interior are only too ready to lay the blame at her door, and they do so in gendered terms: "Cette poufiasse blonde nous met dans un sacré merdier. Les deux autres bougonnent, mais ils sont d'accord...trop jeune, trop belle, trop sûre d'elle" /“"That blonde tart has put us right in the shit.' The other two were muttering, but they agreed...she was too young, too beautiful, too sure of herself" 
(187). The obverse of the high value placed on masculinity in the police force is the association of femininity with weakness or failure. This is also demonstrated in the case of new male recruit Sébastien Doche, who does not demonstrate the requisite masculine attributes of a policeman: he is gentle, considerate, and distressed by avoidable suffering. Consequently, he is marginalized in the Panteuil station and since, for fellow officers, there can be no other explanation for sensitivity in a male officer, Doche is labelled "un pédé" / "a queer" (163).

\section{Sexual Marginalization}

Sex workers comprise a significant marginal group in both Sombre Sentier and Bien connu des services de police, as indeed in all of Manotti's novels. Prostitution and its frequent corollary, sexual violence, are recurrent motifs in these two novels, though they take very different forms. Not all the prostitutes portrayed are presented as victims - those in organized brothels make a good living from well to do clients, including politicians and powerful businessmen. In a way, the latter are themselves victims, susceptible to exploitation by brothel owners who do not hesitate to use surreptitious recording for the purposes of blackmail. However, the narrative focus is usually on the young and often foreign victims of the trade, vulnerable to sexual violence and exploitation. It is no coincidence that Sombre Sentier and Bien connu des services de police both begin with a violent act of sexual aggression on a prostitute. Sombre Sentier opens with the murder of a 12-year old Thai prostitute by a client. The investigation into her death reveals that her murder took place in a Paris club frequented by politicians and businessmen that specializes in the prostitution of minors and in the provision of a video recording service for those who want a souvenir of their activities. The club is supplied by a business ostensibly organizing dance tours but in reality engaged in trafficking underage children from Thailand to provide sexual services. In Bien connu des services de police, three police officers are running a ring of prostitutes from Eastern Europe in a Panteuil car park. The vulnerability of this group is demonstrated graphically in the opening scene of the novel, which features the casual rape of one of the prostitutes by her pimp Paturel. Women do not have to be young or foreign in order to be vulnerable to sexual exploitation. Dorothée Marty was not new to prostitution, but her experience provided her with no protection against rape and, as a member of a socially marginal group, she felt unable to report the incident to the police.

Prostitutes are not the only victims of sexual violence, while policemen are aggressors on more than one occasion. The casual rape of a suspected drugs carrier by a police officer in Sombre Sentier causes only a slight discomfiture on the part of his watching colleague. When the victim reports the rape to Daquin, he offers no sympathy, merely offering payment (accepted by the victim), a gesture that demonstrates tolerance of the officer's reputation as a man who is "aux frontières de la délinquance" / "a borderline delinquent" (20), an attitude all the more disconcerting given Daquin's otherwise compassionate response to the victims of rape. Daquin forms the focus for an interesting reflection on the problematic power relations involved in rape. While Daquin's own experience of rape as a young boy confirms male vulnerability to sexual violence, he is himself guilty of the sexual exploitation, bordering on rape, of his informer Soleiman, whose vulnerability is heightened by the intersection of his ethnic otherness, illegal status, and ambiguous sexuality.12 Intersecting marginalities also exacerbate the vulnerability of a transsexual prostitute who is also part Arab. Despised as a sexual marginal by the police pimps in Bien connu des services de police, he is nonetheless allowed to work for them. However, he becomes an easy target for their anger when the female prostitutes disappear, and Paturel takes out his rage in a violent attack that leaves the 
nameless man hospitalized. Rescued by Ghozali, in whom he senses someone else on the margins, he articulates his acute and multiple sense of alienation, cultural, sexual, and linguistic: "raconter son mal-être, ses errances, ses déchirures entre deux cultures, entre deux sexes, en mêlant français et arabe" / "telling of his malaise, his wandering, torn between two cultures, between two sexes, all in a mixture of French and Arabic" (129).

\section{Social Exclusion}

Manotti extends her scrutiny of marginalized groups to focus on the situation of socially excluded groups in contemporary France, an interest that has its origins in her own past as a political activist. This is particularly the case in Sombre Sentier, where her account of the illegal Turkish workers' fight to regularize their status in France owes much to her personal involvement as a trade union activist in the 1980s in this real life struggle. The marginalization of the Turkish workers is seen most strikingly through Soleiman, who leads the committee working to obtain regularization of their status. He is intimately familiar with the constant fear that accompanies the life of the illegal immigrant and the desire to end that fear: "la peur qu'il faut surmonter quand on voit un flic dans la rue...les fouilles, les nuits dans les postes de police, les arrêtés d'expulsion. Terminé. Nous ne voulons plus" / "the fear you have to overcome when you see a cop in the street...the searches, the nights in police stations, the deportation orders. No more. We've had enough" (13). He observes that for all his sympathy, Daquin, whose sexual marginality is more than offset by his hegemonic cultural and professional status, has never fully experienced this kind of exclusion at the intersection of ethnic, legal, and class marginality, and so can never understand Soleiman's fear.

Bien connu des services de police tackles more recent forms of social exclusion. It is set in 2005, the year of the riots sparked by a police blunder involving the deaths of two youngsters in the Parisian suburbs.13 The novel is located in the fictional suburb of Panteuil but deals with social problems that reflect the all too real problems of the Parisian banlieue. Panteuil is home to a range of marginal groups: illegal workers, immigrants, drug addicts, and gypsies squatting in unoccupied buildings, their marginality reinforced by homelessness. The area is, therefore, politically sensitive and so has remained untouched, frustrating Le Muir's desire to clear it for redevelopment. She is none too particular about the means used to achieve her aim, as she deliberately hints to her driver Pasquini, thus setting in motion the tragedy that subsequently unfolds: " $\mathrm{j}$ 'attends une intervention divine, un miracle, une catastrophe, au choix. Un incendie.. .tout est bon" / "I'm waiting for a divine intervention, a miracle, a catastrophe, the choice is yours. A fire...anything will do" (32). Pasquini who, we learn, has been active in extreme right-wing groups, is only too happy to oblige. The ensuing fire is just one of a series of events that demonstrate the vulnerability of a number of socially excluded groups. Much of the novel's action is located in the local police station, where we see that the treatment accorded to victims of crime varies according to race. Complaints of domestic violence and burglary by members of ethnic minorities are dismissed with comments such as "Si t'es pas content, retourne dans ton pays" / "If you don't like it, go back where you came from" (33), a dismissive attitude in stark contrast to the response to the complaint of a white woman who wrongly believes her mobile phone to have been stolen by "un jeune, de type maghrébin" / "a young North-African looking man" (56). Her allegation generates a misguided police response that escalates into a full-blown incident complete with tear gas, arrests, and the hospitalization of the innocent suspect. The extent of the over-reaction only becomes clear after the event: "Il y avait trente-deux agents....Beaucoup pour un portable, 
dont, de surcroît, rien n'établit qu'il ait été volé" / "There were thirty-two officers....That's a lot for a mobile we can't even prove was stolen" (68).

A further illustration of the way in which youth and ethnicity intersect to lead to a demonization of the young ethnic minorities of the banlieue is seen in the novel's epilogue novel, where Rifat, a young North African, attempts to avenge a friend who has been wrongly convicted of a crime by painting a graffiti message on a motorway bridge. In the middle of his intended message "Flics tueurs on vous tu[e]ra" / "We'll kill you murdering cops" (209), he is spotted by a police patrol who view the opportunity to give chase as "Amusant et sans risque" / "A bit of risk-free fun" (209). Rifat falls from the bridge into the canal below and is deliberately left to drown, the futility of his protest underlined both by his unnecessary death and, symbolically, by the rapid erasure of his tag: "Il aura tenu moins de quarante-huit heures" / "It lasted less than 48 hours" (211). The police are exculpated from blame since their assumption that Rifat is involved in "activités nocturnes répréhensibles et dangereuses" / "reprehensible and dangerous nocturnal activities" (211) remains unchallenged given his ethnic background. The riots of 2005 are not mentioned since the narrative predates them slightly; 14 however, Rifat's death bears sufficient resemblance to the deaths that triggered the riots to suggest hints of the violent reaction to police aggression that was to come.

\section{Narrative Strategies}

Manotti's choice of narrative strategies reflects her desire not to be relegated to a subgenre of crime fiction defined solely by her gender. The creation of tough, independent, solitary investigators together with settings that foreground the darker areas of contemporary French life, such as drug dealing, prostitution, and urban conflict, readily associates her with what have been perceived as the masculine narrative strategies of the roman noir. These together with her gender-neutral pseudonym deceived many a reader into thinking that her work was that of a man.15 It could be argued that her writing style also has a role to play in these assumptions. Manotti herself has observed that no critic detected an "odeur de femme" in Sombre Sentier ("Chéries noires" 91). Leaving aside the loaded question of whether or not writing by women can be said to carry with it an "odeur de femme," of whether or not there is an "écriture féminine," the lack of a gender-specific charge may be explained by Manotti's professional training as an academic historian where dispassionate sifting and presentation of evidence and logical argumentation are paramount. She herself has reflected on the adaptability of the historian's thought processes and research strategies to the task of crime writing: 'L'Histoire comme méthode de pensée et de travail lectures, rencontres, réflexions....Puis construction d'une machine rationnelle ramassant tous les éléments de connaissance accumulés et écriture. Une méthode parfaitement transposable à l'écriture de romans policiers ou noirs" / "History as a method for work and thought: reading, encounters, reflection....Then the construction of a rational mechanism by bringing together and writing up all the known elements. It's a method perfectly adaptable for the writing of detective and noir novels."

\section{Conclusion}

Manotti's reservations about the reductive notion of a polar féminin with its attendant stereotypes have led her to avoid the exclusive focus on matters specific to women's experience or the exclusive use of female investigators that the label implies. Issues which have formed and continue to form part of feminist agendas - sexual violence, rape, prostitution, marginalization, and discrimination - are all present in these novels, and she 
shows that women still suffer because of them, particularly when gender difference intersects with other categories of difference. However, so do men. Despite her disillusionment with the effectiveness of political action and her loss of belief in the possibility of significant political change post 1981, a disillusionment particularly tangible in Bien connu des services de police, Manotti deploys the roman noir in order to speak out on behalf of marginalized and excluded groups of all kinds and, in so doing, to expose the disordered nature of contemporary society. While she has remarked that she does not believe in the power of literature to bring about revolutionary change, she nonetheless considers literature to be a form of political action and sees a value in "tell[ing] the story of the society I know. That's my activism" (Belhadjin, "From Politics to the Roman Noir" 74), thus recognizing her crime fiction to have a political voice. It is no longer a politically aligned voice (though it remains on the left of the political spectrum), nor is it an exclusively female voice. Manotti has camouflaged her gender for a reason, to enable her to speak out for all those, male and female alike, whom society has marginalized. 


\section{Works Cited}

Barfoot, Nicola. Frauenkrimi/polar féminin: Generic Expectations and the Reception of Recent French and German Crime Novels by Women. Frankfurt am Main: Peter Lang, 2007. Belhadjin, Anissa. "From Politics to the Roman Noir." South Central Review 27.1 (2010): 61-81. Project Muse. Web. 28 Sept. 2010.

Belhadjin, Anissa, Lucy Golsan and Sonai Fleury. "Interview with Dominique Manotti."'South Central Review 27.1-2 (2010): 177-81. Project Muse. Web. 28 Sept. 2010. Connell, R. W. Masculinities. Cambridge: Polity, 1995.

Décuré, Nicole. "Roman noir and novela negra: Continuity or Novelty?" Clues 27.2 (2009): 55-65. ProQuest. Web. 17 July 2011.

Desnain, Véronique. "La femelle de l'espèce: Women in contemporary French crime fiction." French Cultural Studies 12 (2001): 175-92.

—. "Gender and Genre: Women in French Crime Writing." Gorrara 86-106.

—. "L'Histoire du crime: The Crime Novels of Dominique Manotti." Hardwick 151-69.

Gorrara, Claire, ed. French Crime Fiction. Cardiff: Wales UP, 2009.

-. The Roman Noir in Post-War French Culture: Dark Fictions. Oxford: Oxford UP, 2003. Hamilton, Deborah. "The French Detective Fiction Novel 1920s to 1990s: Gendering a Genre.” Diss. Pennsylvania State University, 1994.

Hardwick, Louise, ed. New Approaches to Crime in French Literature, Culture and Film. Oxford: Peter Lang, 2009.

Horsley, Lee. The Noir Thriller. Basingstoke: Palgrave, 2001.

Lykke, Nina. Feminist Studies: A Guide to Intersectional Theory, Methodology, and Writing. New York: Routledge, 2010.

Manotti, Dominique. À nos chevaux. Paris: Editions Payot et Rivages, 1997. Dead

Horsemeat. Trans. Amanda Hopkinson and Ros Schwartz. London: Arcadia, 2006.

—. Bien connu des services de police. Paris: Gallimard, 2010.

—. "Biographie,” dominiquemanotti.com. N.p. n.d. Web. 28 Feb. 2010.

—. "Chéries noires." La Raison présente, 134 (2000): 91-96.

—. Le Corps noir. Paris: Editions du Seuil, 2005.

—. "Dominique Manotti: du militantisme à l'écriture tout en parlant de politique."Mouvements, 15-16 (2001): 41-47.

-. Kop. Paris: Editions Payot et Rivages, 1998.

-. Lorraine Connection. Paris: Editions Payot et Rivages, 2006. Lorraine Connection.

Trans. Ros Schwartz and Amanda Hopkinson. London: Arcadia, 2008.

- Nos fantastiques années fric. Paris: Editions Payot et Rivages, 2001. Affairs of State.

Trans. Ros Schwartz and Amanda Hopkinson. London: Arcadia, 2009.

-. Sombre Sentier. Paris: Editions du Seuil, 1995. Rough Trade. Trans. Margaret Crosland and Elfreda Powell. London: Arcadia, 2001.

- . "Splendeurs et mystères du roman noir: Intervention au Colloque de Bari, organisé par les universités de Bari, Bergame et Palerme, 14-15 octobre 2009."

dominiquemanotti.com. N.p. n.d. Web. 28 Feb.2010.

Rolls, Alistair and Deborah Walker. French and American Noir: Dark Crossings.

Basingstoke: Palgrave Macmillan, 2009.

Tabachnik, Maud. "Remarques sur la non-place des femmes dans le roman noir." Les

Temps Modernes 595 (1997): 122-29.

Todorov, Tvetzan. The Poetics of Prose. Oxford: Blackwell, 1977. 


\section{References}

1 DOA (Dead on Arrival) is the author of a number of crime novels, including Citoyens Clandestins, which won the Grand Prix de Littérature Policière in 2007.

2 To date, Sombre Sentier has been translated as Rough Trade (2003); A nos chevaux as Dead Horsemeat (2006); Nos fantastiques années fric as Affairs of State (2009); while Lorraine Connection (2008) has retained the same title in English. Since not all Manotti's novels have been translated yet, the original French title will be used throughout, in the interests of consistency. For the same reason of consistency, all translations into English are the author's own.

3 Manotti has described her own political views as having "une tonalité qu'on pourrait dire marxiste et syndicaliste révolutionnaire"/“a tone that could be described as Marxist and revolutionary syndicalist" (Biographie).

4 Manotti was born in the same year as Jean-Patrick Manchette, often seen as the originator of the genre. Other politically inclined writers of crime fiction belonging to this broadly defined generation include Didier Daeninckx (b.1949), Maurice Gouiran (b.1946), JeanClaude Izzo (b.1945), Thierry Jonquet (b.1954), among others.

5 Desnain's "Gender and Genre" offers a useful introduction to the current state of women's crime writing in the French publishing world.

6 This development is elaborated in the introduction to Hamilton's thesis (1-22). Desnain's “"La femelle de l'espèce»" also contains an outline of the development of women's crime fiction in France.

7 "Polar" is a frequently used generic term for crime fiction in France.

8 Hamilton's thesis offers further detail about the Saint Nazaire festival of 1992 and its effective silencing of women (13).

9 This epithet, used by an unnamed critic from Lire, features on the back cover of both novels published by Le Seuil: Sombre Sentier and Le Corps noir.

10 However, in A nos chevaux, an incident in which compromising photographs of Daquin with a male lover are used in an attempt to blackmail him demonstrates a level of vulnerability in the predominantly macho environment of the police force.

11 A nos chevaux features a similar incident when Daquin interviews a woman still traumatized by her rape by a policeman twenty years earlier.

12 We learn that Soleiman had made a living as a male prostitute in Turkey, but it is never made clear whether Soleiman accepts Daquin's sexual demands because he has no choice or because he is, like Daquin, bisexual.

13 In October 2005, Paris erupted into urban violence, triggered by a police blunder. Two teenagers, believing they were being followed by police as they returned home from a football match, took refuge in an EDF transformer. They were electrocuted. That evening, riots broke out in Clichy-sous-Bois and spread rapidly throughout the Parisian suburbs, making international headlines. 
14 The riots began in late October, while the end of the novel is dated to the night of the 7-8 September 2005.

15 Desnain makes this point in "La femelle de l'espèce" (179). 